\title{
Problems of informatization of higher school in the perception of subjects of the educational process
}

\author{
Irina Viktorovna Tsvetkova*, Olga Anatolevna Bezgina, Olga Sergeevna Evchenko, \\ Vladimir Alekseevich Gurov, and Svetlana Yurevna Vasileva \\ Togliatti State University, Department of History and Philosophy, Togliatti, Russia
}

\begin{abstract}
The relevance of the topic is due to the widespread use of information technology in higher educational institutions. This trend has conflicting and ambiguous consequences. On the one hand, the use of information technology increases the accessibility of education, makes the educational process flexible, and expands the possibilities of using visual materials. On the other hand, problems arise in the development of teaching methods that are necessary to stimulate the learning activity of students. To study the attitude of teachers and students to the problems of using information technology in higher education, the scientific publications of foreign and Russian scientists were analyzed. The purpose of the research is to study the peculiarities of perceiving the problems of informatization of the educational process by teachers and students of higher educational institutions. The empirical basis of the study was the materials of a sociological survey conducted among students of Togliatti State University in $2014(\mathrm{~N}=359)$ and in $2019(\mathrm{~N}=353)$. Comparative analysis of the results shows that within five years the number of students who are interested in using information resources in the educational process has significantly increased. A similar trend can be traced in the interest in using educational programs and simulators. From 2014 to 2019, the number of students who would like to receive supplementary training in information technology has doubled. The growing interest of students in the use of information technology necessitates the development of modern teaching methods, changes in the forms of interaction between students and teachers in the educational process. The solution to these problems at the present stage is associated with the search for the optimal combination of information and interactive technologies in the educational process.

Keywords: educational information, information transfer and development, computers and development
\end{abstract}

\section{Introduction}

The introduction of information technology (IT) in higher educational institutions is an urgent problem for teachers and students in various regions of the world. Despite the socio-

\footnotetext{
* Corresponding author: aleksandr.kozlov@mail.ru
} 
cultural differences in the regions in which the universities are located, there are general trends in implementing IT in the educational process.

The purpose of the article is to characterize the attitude of teachers and students of higher educational institutions to the processes of informatization of higher school based on the analysis of publications of foreign and Russian researchers, as well as materials of the authors' sociological survey.

The research objectives:

- To identify the positive aspects of implementing IT in the educational process in higher educational institutions;

- To analyze the problems of implementing IT at universities;

- To study the ways to solve the problems of informatization of higher educational institutions.

The research hypothesizes that the modern stage of the informatization of higher school has a positive impact on the quality of education, provided that there is an optimal combination of information and interactive technology.

In 2020, a survey of 16,906 teachers was conducted at US colleges and universities, in which the respondents were asked how digital technologies are integrated into students' learning strategies. $62.1 \%$ of respondents noted a high level of integration, and $36.4 \%$ of respondents consider it significant. Only $1.5 \%$ of survey participants do not consider the level of integration to be significant for the educational strategy of an educational institution.

When answering the question regarding the level of efficiency of using IT in the educational process, $24 \%$ of respondents assessed them as very effective, $62.9 \%$ of respondents believe that they are effective in some cases, low efficiency was noted by $11.2 \%$ of respondents, and $1.9 \%$ of respondents do not consider them effective.

The research participants were asked about the impact of IT on student performance. $95.6 \%$ of surveyed teachers acknowledge the impact of digital technology on student performance [1].

The positive impact of IT on student learning outcomes is not the same across all specialist fields. For humanitarian students, the use of general Internet applications is more effective than special educational applications [2].

In the educational systems of technologically advanced countries, learning is closely linked to technology, which is an integral part of everyday life. The goals of education are to provide students with the skills and abilities for self-development in the conditions of uncertainty [3].

Educational practices with the use of IT must take learning to a higher level [4]. The quality of online education should not be lower than the quality of education using traditional methods.

The low level of IT mastery by teachers, resistance to their use, as well as the lack of institutional support are the main problems of introducing informatization in higher education [5].

The process of transitioning courses to online learning at a university is transforming the teaching experience and methodology. There is a transition from direct interaction of teachers and students to virtual, online or web contact [6].

Russian scientists note the need for informatization of the higher education system in connection with the training of competitive specialists [7].

The use of IT in the higher education system contributes to an increase in the availability of educational resources, a reduction in the time for conducting interim attestation, as well as an expansion of the possibilities of visual teaching [8]. In modern society, the concept of "information educational environment" is replacing the educational environment [9]. 
The solution to the problem of creating an information educational environment is associated with developing methodological support for the educational process at the higher educational institution [10]. Information technology, as such, is not able to influence the quality of students' assimilation of information. The introduction of IT changes the meaning of traditional forms of education, for example, such as lectures [11].

Distance learning is widely used in higher educational institutions. This enables students to participate in the educational process, despite the spatial distance. The research results show that students, in general, positively assess distance learning [12].

When analyzing the experience of using digital educational platforms, it was found that virtual interactions are not able to stimulate the cognitive activity of students [13]. There is a requirement for the creation and practical implementation of interactive teaching tools [14].

Communication of students with artificial intelligence has a certain potential for enhancing learning using IT. This practice gives students a useful experience in understanding their own psychological characteristics [15]. Thus, the analysis of publications on introducing informatization in higher school indicates that this problem is relevant for foreign and Russian scientists. To solve it, it is required to take into account the attitude of students to implementing IT in the educational process.

\section{Methods}

The empirical basis of the study is the data obtained as a result of the online sociological survey among students of Togliatti State University in 2014 ( N=359) and in 2019 ( N=353).

The results of the survey enabled to study the attitude of 1-4-year students to the use of information technology in the educational process.

The materials were processed using the SPSS-23 statistical program. Comparing the results for 2014 and 2019 reveals trends in the attitude of survey participants to the use of information technology in the educational process.

\section{Results and discussion}

The relevance of studying the attitude of students to the use of information technology in the educational process is due to the fact that a lot of work is being done at Togliatti State University to introduce distance learning technologies. Currently, about two-thirds of TSU students study remotely. The development of the remote form began long before the pandemic and is currently being conducted on the "Rosdistant" platform. Distance learning technologies are actively being introduced into the process of teaching full-time students. In particular, for full-time students, lectures on some humanitarian subjects (history, philosophy, etc.) are conducted with the help of educational materials developed by teachers for "Rosdistant". Thus, the information technology used at TSU for distance learning complements the traditional forms of educational work.

Table 1 presents the answers of the survey participants to the question regarding their readiness to use information technology in their studies. Respondents answer to the question: "Which of the technologies offered below would you like to use?" depending on training course. Results are presented in \% according to the answer option "ready to use".

Table 1. Survey results.

\begin{tabular}{|l|c|c|c|c|c|}
\hline Information technology & $\begin{array}{c}\text { By } \\
\text { array }\end{array}$ & $1^{\text {st }}$ year & $2^{\text {nd }}$ year & $3^{\text {rd }}$ year & $4^{\text {th }}$ year \\
\hline
\end{tabular}




\begin{tabular}{|l|c|c|c|c|c|}
\hline Use of Internet resources & 87 & 91 & 88 & 82 & 88 \\
\hline $\begin{array}{l}\text { Methodological materials in electronic } \\
\text { form }\end{array}$ & 69 & 66 & 71 & 68 & 73 \\
\hline $\begin{array}{l}\text { Educational computer programs and } \\
\text { PC simulators }\end{array}$ & 68 & 73 & 63 & 59 & 74 \\
\hline Consultations by e-mail & 54 & 48 & 45 & 58 & 61 \\
\hline On-line consultations & 53 & 63 & 45 & 49 & 53 \\
\hline
\end{tabular}

Even $87 \%$ of respondents answered that they are ready to use Internet resources in their studies. About two-thirds of the respondents (69\%) want to use the methodological materials in electronic form. The number of students interested in using educational computer programs and PC simulators amounts to $68 \%$ of the respondents. Only half of the respondents are ready to use consultations by e-mail or on-line.

In 2019, compared to 2014, significant changes occurred in the needs of students for Internet resources, as well as in educational computer programs and PC simulators that they would like to use in their studies (See Figure 1).

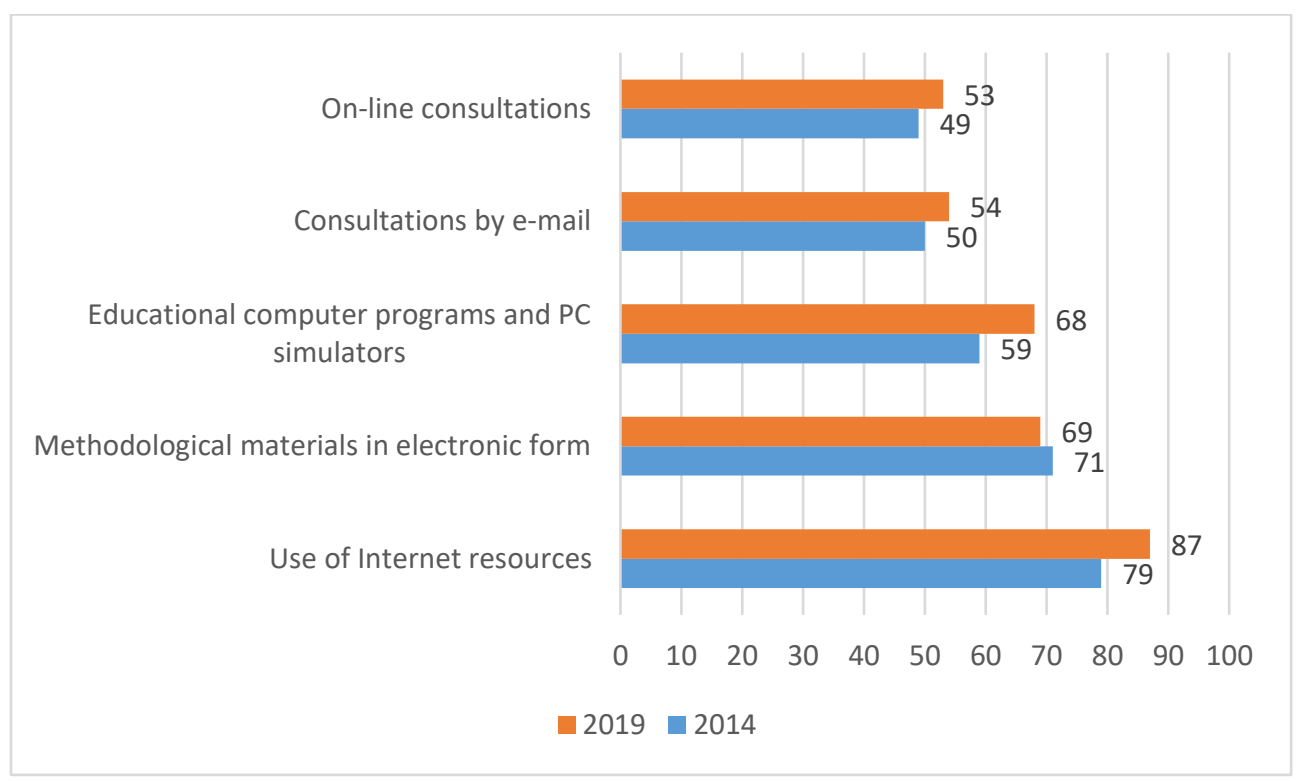

Figure 1. Dynamics of students' interest in using information technology in studies (in \%).

Table 2 shows that the number of students who require advanced training in IT has doubled in five years. There are by 1.6 times more students who consider it necessary to develop their communication skills. The number of students (by 1.3-1.4 times) who are interested in getting marketing, economic training, as well as legal knowledge preparation has significantly increased. At the same time, there is a decrease in the number of respondents who would like to acquire practical skills in the course of production training.

Table 2. Dynamics of TSU students' requirements for additional training (in \% by columns).

\begin{tabular}{|l|c|c|c|}
\hline Directions of additional training & $\mathbf{2 0 1 4}$ & $\mathbf{2 0 1 9}$ & Coefficient of changes \\
\hline Increase in production training & 57 & 44 & 0.78 \\
\hline
\end{tabular}




\begin{tabular}{|l|c|c|c|}
\hline Development of communication skills & 39 & 61 & 1.6 \\
\hline $\begin{array}{l}\text { Advanced training in information } \\
\text { technology }\end{array}$ & 19 & 38 & 2 \\
\hline Marketing preparation & 19 & 24 & 1.3 \\
\hline Basics of economic knowledge & 19 & 26 & 1.4 \\
\hline Law basics & 18 & 26 & 1.4 \\
\hline
\end{tabular}

The growth in the need for additional training is due to the introduction of project activities at TSU, in which students participate from the 1st to the 4th year. Many projects implemented by students are related to the use of information technology. For example, within the framework of the project "Innovative educational space of the TSU historical museum", students create a modern model of a museum in a virtual space. Developing materials for the museum, students receive historical knowledge of local history, as well as acquire the skills of searching, editing, and publishing research results in the information space. Thus, mastering information technology is closely related to the educational and project activities of students.

\section{Conclusion}

The use of information technology in higher school is an urgent problem for teachers and students. Teachers, judging by scientific publications, consider information technology as a means of increasing the accessibility of education, expanding the possibilities of disseminating educational information, and exercising operational control over the acquisition of the educational program by students. However, the use of IT in the educational process creates a number of difficulties for teachers. They consist in the requirement to create educational materials for the use in the information environment, interactive teaching methods, and the formation of incentives for students to obtain qualitative knowledge. The results of the survey of students indicate an increase in students' interest in using IT in their studies. This interest is mainly associated with the use of Internet resources, methodological materials in electronic form, as well as educational programs. Against this background, students have an increasing need for additional training in information technology, which is implemented in educational and project activities. Thus, the use of IT in higher school brings to the fore the problem of the quality of education, the solution of which is associated with the optimal combination of information and interactive technologies.

\section{References}

1. L. Davis, Digital Learning: What to Know in 2020. Accessed on: July 17, 2021.

[Online]. Available: https://www.schoology.com/blog/digital-learning

2. S. Chauhan, P. Gupta, S. Palvia, V. Jaiswal, J. Inf. Tech. Case and Appl. Res. 23(1), 335 (2020). https://doi.org/10.1080/15228053.2020.1846480

3. M. Liesa-Orús, C. Latorre-Cosculluela, S. Vázquez-Toledo, V. Sierra-Sánchez, Sustainability, 2(13), 5339 (2020). https://doi.org/10.3390/su12135339

4. U.Kr. Pegu, Int. J. Inf. Comp. Tech. 4(5), 513-518 (2014)

5. S.P. John, Contaduría y Admin. 60(1), 230-252 (2015). https://doi.org/10.1016/j.cya.2015.08.004 
6. S. Dintoe, Int. J. Edu. Devel. Inf. Commun. Tech. 14(2), 121-166 (2018)

7. E.A. Krainova, A.V. Tarakanov, A.S. Savin, Probl. Modern Pedag. Edu. 59(2), 114118 (2018)

8. T.Yu. Dunaeva, Probl. Pedag. 4(27), 71-73 (2017)

9. Z.S. Fargieva, M.Kh. Malsagov, M.T. Agieva, Z. Agieva, Int. Sci. Rev. 7(17), 77-80 (2016)

10. A.A. Gerich, Int. J. Human. Nat. Sci. 3, 65-67 (2018)

11. V.N. Kruglikov, Soc. Comm. Edu. 1, 142-151 (2017). https://doi.org/10.187217JHSS.8117

12. T.L. Kuzmenkova, et al., Innov. Proj. Prog. Edu. 6(66), 23-27 (2019)

13. N.Kh. Saveleva., et al., ANI: Pedag. Psy. 4(33), 201-204 (2020). https://doi.org/10.26140/anip-2020-0904-0043

14. V.V. Maliataki, K.A. Kirichek, A.A. Vendina, Open Edu. 3, 56-66 (2020). http://dx.doi.org/10.21686/1818-4243-2020-3-56-66

15. T.V. Salynskaya, M.S. Tolkunova, Modern Pedag. Edu. 11, 172-177 (2020) 